\title{
IRS1 wt Allele
}

National Cancer Institute

\section{Source}

National Cancer Institute. IRS1 wt Allele. NCI Thesaurus. Code C52397.

Human IRS1 wild-type allele is located in the vicinity of $2 q 36$ and is approximately $65 \mathrm{~kb}$ in length. This allele, which encodes insulin receptor substrate 1 protein, is involved in the progression of signaling from both insulin and cytokine-responsive receptors. 